\title{
Exogenous melatonin as potential adjuvant in anti-SarsCov2 vaccines
}

\author{
Georges Maestroni ${ }^{1}$
}

Received: 13 August 2020 / Accepted: 7 September 2020 / Published online: 10 September 2020

(C) Springer Science+Business Media, LLC, part of Springer Nature 2020

Dear Prof. Gendelman:

Melatonin MLT) or N-acetyl-5-methoxy-tryptamine is an indoleamine synthesized and immediately secreted in the blood during the night darkness hours by the pineal gland. Circulating MLT has the fundamental role of synchronizing the organism in the photoperiod (Claustrat and Leston 2015). MLT may, however, be synthesized in many other organs and cell types including primary and secondary lymphoid organs as well as circulating immunocompetent cells. Extra pineal MLT does not contribute to the circulating pool and conveys only autocrine or paracrine signals (Maestroni 2001).

Being an ancient molecule, MLT developed several pleiotropic effects. Probably the most primordial of these involve the direct interaction of MLT with other molecules as in the case of its well-known powerful antioxidant action. Then during evolution, MLT became gradually a classical hormone acting through specific receptors. In mammals there are two type of membrane receptors, MT1 (MTNR1A, in humans) and MT2 (MTNR1B in humans). Both MT1 and MT2 may be found in almost all tissues as heterotrimeric Gi/ Go and Gq/11 proteincoupled receptors interacting with downstream messengers such as adenylyl cyclase, phospholipase A2 and phospholipase C, decreasing cAMP and cGMP production and/or increasing diacylglycerol and IP3 formation. Furthermore, MLT might interact at the nuclear level with retinoid orphan receptors/ retinoid Z receptors (Jockers et al. 2016).

One of the most interesting property of MLT is its ability to modulate the immune response. The first evidence that MLT could increase the IgG antibody response and counteract the immunosuppressive effect of corticosteroid and/or acute stress was provided by myself some decades ago (Maestroni et al. 1987; Maestroni 2001). The immunoregulatory role of MLT is today widely accepted. It has been proposed that MLT may

Georges Maestroni

georges.maestroni@tim.it

1 Center of Research in Medical Pharmacology, University of Insubria, Varese, Italy act as an immune buffer, stimulating the immune response under basal or immunosuppressive conditions or exerting an anti-inflammatory action in the presence of exaggerated immune responses (Carrillo-Vico et al. 2013; Mortezaee et al. 2019). This double-edged effect may depend on the ability of MLT to interfere with $\mathrm{T}$ cell differentiation and control the balance between pathogenic and regulatory T cells. MLT can promote the differentiation of type 1 regulatory $\mathrm{T}$ cells via extracellular signal regulated kinase 1/2 (Erk1/2) and retinoic acid-related orphan receptor- $\alpha$ (ROR- $\alpha)$ and suppress the differentiation of Th17 cells via the inhibition of ROR- $\gamma \mathrm{t}$ and ROR- $\alpha$ expression through NFIL3.

In relation to viral diseases, MLT proved to counteract the infection in variety of models (Maestroni 2001) and recently it has been suggested to be of potential therapeutic value in reducing the severity of Covid-19 (Shneider et al. 2020). As a matter of facts, Covid-19 may be remarkably severe in elderly males, i.e. in a population in which plasma levels of MLT may be particularly low (Touitou et al. 1985).

As far as it concerns vaccines, several studies demonstrated that exogenous MLT may act as an adjuvant enhancing both CD8 + T cell response in cancer vaccines (Moreno et al. 2018; Baghdam Rahimi et al. 2018) and humoral responses against a variety of pathogens (Regodon et al. 2005).

Recently it has been demonstrated in an animal model that melatonin enhances the immune response to a vaccine by increasing peripheral blood CD4 $+\mathrm{T}$ cells and IgGexpressing B cells (Ramoset al. 2008). This finding is particularly interesting as a recent study in Covid-19 convalescent patients, found a vigorous $\mathrm{CD} 4^{+} \mathrm{T}$ cell responses to spike protein, the main target of most vaccines, and that such a response correlated with the level of the anti-SARS-CoV-2 IgG and IgA titers (Grifoni et al. 2020).

However, in some patients the immune response might not be sufficient as relapses have already been reported, so it appears that long-term natural immunity might not prevent the current and future outbreaks (Papachristodoulou et al. 2020). Therefore, the development of an effective vaccine is commanding to control the disease. Most interesting, critically ill 
Covid-19 patients show a decreased number of circulating CD8 + T cells due to the inhibition of IL-2 and IL-2R (Shi et al. 2020). MLT is well known to stimulate IL-2 production and by doing this increase both CD $4+$ and CD $8+T$ cells number (Carrillo-Vico et al. 2013). Thus, its use in antiSars-Cov-2 vaccines may potentiate the type of immunity that is most effective against the virus.

In conclusion, administration of exogenous MLT might well boost the potency of the immune response and duration of the vaccine-induced immunity. Perhaps MLT administration might be especially useful in elderly males, but the existing evidence point to a general capacity of MLT to enhance both cell-mediated and humoral immune responses irrespective to sex and age. Ideally, the protocol of oral administration should use a dosage able to induce a sustained plasma concentration of the hormone for at least 7-8 hours during the night. MLT displays a short blood half-life, so fast release preparations should be administered at a high dose (several mg per day), while prolonged release preparations can be administered at $2 \mathrm{mg}$ per day. Administration of suprapharmacological doses of MLT should be avoided as such doses may decrease the immune response (Maestroni et al. 1987). The kinetic of the MLT effect on the immune response is not well known. In animals, MLT administration is effective when given for a week or so after the antigen challenge (Maestroni 2001). So the duration of MLT administration in case of the vaccine against SARS-Cov-2 should not be shorter and also it may vary according to the type of vaccine used. In case of adenoviral vectors it should probably be prolonged due to the gradual antigenic endogenous release of the antigen. It has, however, been reported that in a DNA vaccine against cancer, MLT induced a sustained potentiation of its anti-cancer effect, inhibiting tumor growth over the time without a prolonged administration (Baghban Rahimi et al. 2018).

Exogenous MLT is well tolerated and may produce only mild adverse effects mostly related to its ability to alter sleep structure (Claustrat and Leston 2015). Last but not least, due to its antioxidant properties and its pleiotropic effect on the immune system MLT might also prevent adverse effects of the vaccine.

Acknowledgements I thank Prof. Marco Cosentino for his constructive criticism and precious help to improve this letter.

\section{References}

Baghban Rahimi S, Mohebbi A, Vakilzadeh G, Biglari P, Jahromi SR, Mohebi SR, Shirian S, Gorji A, Ghaemi A (2018) Enhancement of therapeutic DNA vaccine potency by melatonin through inhibiting VEGF expression and induction of antitumor immunity mediated by CD8 + T cells. Arch Virol 163(3):587-597. https://doi.org/10.1007/ s00705-017-3647-z

Carrillo-Vico A, Lardone PJ, Alvarez-Sánchez N, Rodríguez-Rodríguez A, Guerrero JM (2013) Melatonin: buffering the immune system. Int J Mol Sci 14(4):8638-8683. https://doi.org/10.3390/ijms14048638
Claustrat B, Leston J (2015) Melatonin: Physiological effects in humans. Neurochirurgie 61(2-3):77-84. https://doi.org/10.1016/j.neuchi. 2015.03.002

Grifoni A, Weiskopf D, Ramirez SI, Mateus J, Dan JM, Morderbacher CR, Rawlings SA, Sutherland A, Premkumar L, Jadi RS, Marrama D, de Silva AM, Frazier A, Carlin AF, Greenbaum JA, Peters B, Krammer F, Smith DM, Crotty S, Sette A (2020) Targets of T cell responses to SARS-CoV-2 coronavirus in humans with COVID-19 disease and unexposed individuals. Cell 181(7):1489-1501.e15. https://doi.org/10.1016/j.cell.2020.05.015

Jockers R, Delagrange P, Dubocovich ML, Markus RP, Renault N, Tosini G, Cecon E, Zlotos DP (2016) Update on melatonin receptors: IUPHAR Review 20. Br J Pharmacol 173(18):2702-2725

Maestroni GJ (2001) The immunotherapeutic potential of melatonin. Expert Opin Investig Drugs 10(3):467-476. https://doi.org/10. 1517/13543784.10.3.467

Maestroni GJ, Conti A, Pierpaoli W (1987) Role of the pineal gland in immunity: II. Melatonin enhances the antibody response via an opiatergic mechanism. Clin Exp Immunol 68(2):384-391

Moreno ACR, Porchia BFMM, Pagni RL, Souza PDC, Pegoraro R, Rodrigues KB, Barros TB, ASps LRMM, de Araujo EF, Calich VLG, Ferreira LCS (2018) The combined use of melatonin and an indoleamine 2,3-dioxygenase-1 inhibitor enhances vaccine-induced protective cellular immunity to HPV16-associated tumors. Front Immunol 9:1914. https://doi.org/10.3389/fimmu.2018.01914

Mortezaee K, Potes Y, Mirtavoos-Mahyari H, Motevaseli E, Shabeeb D, Musa AE, Njafi M, Farhood B (2019) Boosting immune system against cancer by melatonin: A mechanistic viewpoint. Life Sci 238:116960. https://doi.org/10.1016/j.lfs. 2019.116960

Papachristodoulou E, Kakoullis L, Parperis K, Panos G (2020) Longterm and herd immunity against SARS-CoV-2: implications from current and past knowledge. Pathog Dis 78(3):ftaa025. https://doi. org/10.1093/femspd/ftaa025

Ramos A, Míguez MP, Morgado S, Sanchez-Correa B, Gordillo JJ, Casado JG, Tarazona R, Regodon S (2008) Melatonin enhances responsiveness to Dichelobacter nodosus vaccine in sheep and increases peripheral blood CD4 T lymphocytes and IgG-expressing B lymphocytes. Vet Immunol Immunopathol 206:1-8. https://doi.org/ 10.1016/j.vetimm.2018.11.006

Regodón S, Martín-Palomino P, Fernández-Montesinos R, Luis Herrera J, Pilar Carrascosa-Salmoral M, Piriz S, Vadillo S, Guerrero JM, Pozo D (2005) The use of melatonin as a vaccine agent. Vaccine 23(46-47): 5321-5327. https://doi.org/10.1016/j.Vaccine.2005.07.003

Shi H, Wang W, Yin J, Ouyang Y, Pang L, Feng Y, Qiao L, Guo X, Shi $\mathrm{H}$, Jin R, Chen D (2020) The inhibition of IL-2/IL-2R gives rise to $\mathrm{CD}^{+} \mathrm{T}$ cell and lymphocyte decrease through JAK1-STAT5 in critical patients with COVID-19 pneumonia. Cell Death Dis 11(6): 429. https://doi.org/10.1038/s41419-020-2636-4

Shneider A, Kudriavtsev A, Vakhrusheva A (2020) Can melatonin reduce the severity of COVID-19 pandemic? Int Rev Immunol 39(4): 153-162. https://doi.org/10.1080/08830185.2020.1756284

Touitou Y, Fevre-Montange M, Proust J, Klinger E, Nakache JP (1985) Age- and sex-associated modification of plasma melatonin concentrations in man. Relationship to pathology, malignant or not, and autopsy findings. Acta Endocrinol (Copenh) 108(1):135-144. https://doi.org/10.1530/acta.0.1080135

Publisher's Note Springer Nature remains neutral with regard to jurisdictional claims in published maps and institutional affiliations. 